\title{
COMMERCIALISATION OF PUBLIC HOSPITALS LOCATED IN THE SILESIAN REGION - RESULTS OF OWN RESEARCH STUDIES
}

\author{
KAROLINA WIELICKA-GAŃCZARCZYK
}

Silesian University of Technology Faculty of Organization and Management, Zabrze, POLAND e-mail: Karolina.Wielicka-Ganczarczyk@polsı.pl

RECEIVED
ACCEPTED
JEL
CLASSIFICATION

KEYWORDS

ABSTRACT

\author{
8 August 2017 \\ 15 December 2017 \\ I18, H41, H63, G34 \\ healthcare system, public hospital, restructuring, commercialization, Poland
}

The article presents actions undertaken by public hospitals located in the Silesian Region during commercialisation, which is one element of hospital restructuration. The paper is divided into two parts. In the first one explained the differences between hospital commercialisation and privatisation. The second one presents selected results, which were part of more extensive research about the effectiveness of restructuring process in hospitals located in the Silesian Region. The above-quoted research studies were aimed to assess the effectiveness and its unsatisfactory reasons of restructuring processes taking place in hospitals. The research study was preceded by pilotage and conducted in three stages, for which was used triangulation of methods. At the first stage, the process of restructuration as perceived from public hospitals was analysed, at the second stage - their commercialization, the last one concentrated on restructuring process in commercialized hospitals. The results provided in the paper concerns the second stage and based on surveys conducted among managing staff of commercialised hospitals who participated in the and held managerial positions at the time. The results show the reasoning standing behind decisions made on the commercialisation of hospitals, planned actions in relation to project management and results of such actions after their implementation i.e. effectiveness of the whole process as well as all such actions undertaken in individual fields. The research was conducted in 2013 to 2015 , on necessary sample size of 11 entities at 0.9 level of confidence and 0.15 for statistical error. The paper aim is to demonstrate selected results about planning and implementation of actions undertaken by public hospitals located in the Silesian Region under their commercialisation.

\section{Introduction}

Undoubtedly, the healthcare sector (in which, in particular, care treatment provided by hospitals makes the foundation of ensuring public health) is one of the basic elements in the economy. The issue of insufficient funds needed for the proper operation of hospitals has been tackled by reforms implemented for several decades and forcing their stepped restructurisation. 
Numerous scholarly publications combine a notion of 'comercialisation' with a concept of 'process'. It is customary to write and speak about a "restructuring process" in reference to some interrelated operations rather than their continuity, as in the case of continuous improvement in a company where such a process is uninterrupted. A scope of implemented changes (which, in principle, stand for a fundamental change in a company) makes the common denominator of some definitions. As for hospitals, this change undoubtedly refers to commercialisation, which itself is a legal-administrative process only but still can be also part of broader operations undertaken under restructurisation. Taking into consideration that an in-depth reconstruction is not a natural state for any organisation, it can be assumed that restructurisation stands for a transitional and exceptional operation with its starting and ending points. Bearing in mind the above, it should be stated that restructurisation has some characteristics of a project and thus actions undertaken within it should be planned, implemented and monitored in accordance with the standards adopted for project management. The research studies presented in this paper on planning operations under hospital commercialisation in the Silesian Region were analysed in project-management terms.

\section{Commercialisation and privatisation}

Propagation of misleading information by the media for years (commercialisation mistaken for privatisation) led to an increase in resistance of the Polish society towards the transformation of hospitals. The Polish society identifies commercialisation with privatisation (Wiercińska, 2015, p. 458), and, consequently, with elimination of free healthcare treatment and its replacement with commercial one.

So, in case of hospitals, commercialisation, in other words, stands for a transformation of a business entity which operates as an independent public health-care institution (pol. SPZOZ) into a capital company (Horosz, 2012, p. 22). With its scope it only refers to changes made to the organisational and legal form of an individual hospital, not to its ownership. It means that a business entity which establishes a public hospital once it is transformed becomes the key shareholder of a newly established company, thus its owner remains the same and the procedure itself can be called a cosmetic change. The adopted Act on healthcare treatment (the Act, 2011) permitted its establishing entity to select one of the following two options - liquidation or commercialisation of a given hospital in case its debts cannot be repaid. Taking into consideration that the first option could not be applied in practice, commercialisation was the primary solution to the issue of hospital over-indebtedness; all the more the Act itself applied mechanisms which favoured this solution (Marcinkowska, 2016, p. 426). The simplicity of this procedure (to implement commercialisation) was one of them. The prior Act on healthcare institutions (the Act, 1991) allowed to transform a public hospital into a commercial law company upon having undertaken the following actions: adoption of a resolution on the liquidation of a given hospital, setting-up a non-public health-care institution (pol. NZOZ), adoption of a resolution to manage assets of a liquidated hospital and appointing its liquidator, then liquidation, delegation of public service to provide health-care treatment to this non-public health-care institution (pol. NZOZ) and assets to the founding body and finally - adoption of a resolution on the completion of liquidation of a given hospital and dismissal of its social council. The Act on healthcare treatment significantly simplified the whole process by bringing it into a deed of transformation, which additionally contained a deed of incorporation of a given company itself. Upon its preparation, such a newly created entity was required to be entered into the register of entrepreneurs, which resulted in the deletion of public hospital from the National Court Register and completion of all transformation (Rabiega-Przyłęcka, 2013, p. 20). Taking into account the procedure and application of mechanisms which pressed for immediate debt relief, it can be stated that - in order to accelerate the process - the legislator 
simplified it to a large extent. Nevertheless, the ownership of this newly established company did not change - its establishing entity became its principal owner.

The concept of privatisation can be applied twofold. The first approach incorporates a set of actions leading to a change in the structure of ownership of business entities in an individual country in favour of the private sector, while - at the same time - its reduced involvement in the economy. The second approach aims to transform what is owned by the state into non-state property (Stępniak-Kucharska, 2015, pp. 136-137), which could be done through sale or appropriation (Kocowski, 2012, pp. 38, 45). The concept of privatisation could be easily referred to public hospitals if there were no legal regulations limiting the freedom of direct privatisation of hospitals. In line with the Act on healthcare treatment (the Act, 2011), hospitals, apart from clinics, could be privatised only upon their commercialisation (Karkowski, 2014, p. 150). It means that it was the key shareholder (i.e. a business entity establishing such a transformed public hospital) which/who decided on its further transformation. Currently (since 2016) the current legislation has not allowed to privatise hospitals (the Act, 2016). Owners of commercialised hospitals are not allowed to sell hospital stocks or shares to private-sector entities if they lose their majority stake this way. Moreover, the Act lets to establish hospitals in the form of an independent public health-care institution (pol. SPZOZ) and settles responsibility for the financial standing (especially negative result) of a given hospital entrusting its settlement first to this hospital and then - in case of failure to cover losses - to its establishing entity.

Supporters for commercialisation believe that this is a good solution aimed to reduce operating costs incurred by hospitals and increase the quality of services they provide. Treatment of health care services and other services in the same manner (and a hospital itself like a free-market operator) is aimed to improve the competitiveness of healthcare providers, which, in turn, will lead to increased availability of their services and elimination of waste (Brzozowska-Woś, 2013, p. 35). Taking into account some reports on the commercialisation of hospitals published by the Supreme Chamber of Control (NIK, 2014, p. 8) and the Magellan Group (Magellan, 2014, p. 5) or the author's research results, it must be stated that this opinion is partially true only.

\section{Specification on participation criteria and applied research methods}

The results of the author's research studies included in this paper were based questionnaires taken from 12 hospitals which met the following participation criteria. Such hospitals:

a) provided medical treatment in the form of stationary and all-day hospital services;

b) held more than one multi-specialisation division in their organisational structure;

c) were transformed from a hospital functioning as an independent public health-care institution (pol. SPZOZ) for which the Governor of the Silesian Region or any other local government unit located in the Silesian Region was their establishing entity;

d) held no scientific and didactic facilities for any medical school;

e) their medical activities were not leased (partially or wholly) to any another other business entity;

f) held no ministerial entities in the capital structure;

g) were not leased to any private business units;

h) were not partially/fully privatised;

i) held no divisions belonging to any external entities in their structure.

The questionnaire consisted of 42 questions, of which 4 covered respondents' particulars, 20 referred to the planning of commercialisation, 12 - to its implementation and 6 - to its results. 


\section{Selected research resullts for the Sillesian region}

In the survey took part 17 persons from 12 transformed hospitals. In the course of commercialisation they held managerial posts. Prior to the transformation process each of the surveyed entities held more than 8 multispecialisation divisions. The smallest hospital participating in the survey consisted of 4 divisions while the largest one - 13. More than one in three (six respondents) held one- or four-person management. As for three of the respondents their management was made up of two people and as for the rest of the persons participating in the study - three people in the board.

\section{Reasons for the commercialisation of public hospitals}

According to most of the respondents (sixteen people) the major reason why hospitals were commercialised lies in that, it was necessary to re-condition them vulnerability (the need for repair). More than $1 / 3$ of the respondents considered that their transformation was due to that they wanted to be independent from their establishing entity and adjust to changes taking place in the environment. Only five of the respondents regarded that hospitals were commercialised because they wished to get developed. The reasons specified above were a prerequisite to define the key goal of commercialisatios. Two main goals for commercialization process were identified by six of the respondents $(35.3 \%)$, five persons defined $(29.4 \%)$ - three, four respondents - one and two specified four main objectives for the commercialization process. For most of the respondents, these goals were shown in a Figure 1 below.

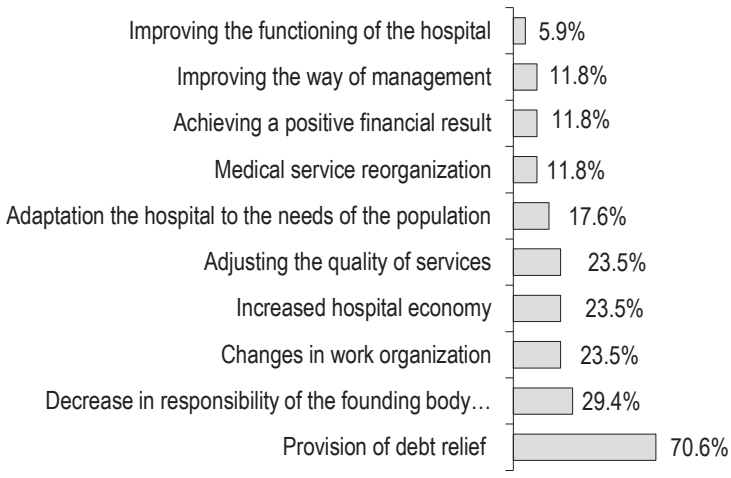

Figure 1. The main purpose of the commercialization process

Source: own elaboration.

The hospitals with 8 to 13 divisions as the main purpose of commercialization the most often adopted: increased hospital economy, improving the way of management and medical service reorganization. In turn, the hospitals whit 4 to 7 divisions defined: changes in work organization, adaptation the hospital to the needs of populations and improving the functioning. For five respondents from hospitals with 8 to 13 divisions and seven from 4 to 7 health care divisions point at lack of debt as their main aim. 


\section{Actions undeptaken by hospitals while planning commercialisation}

According to the nine respondents $(52.9 \%)$, no project team was set up to run restructuring operations covering commercialisation of a given hospital. The remaining respondents set up a project team with its members being appointed by management of their hospital or founding body (now the establishing entity) (four persons in both cases). The question on persons responsible for planning restructuring activities was answered by all the respondents, even the ones who in the previous question declared that no project team was appointed. In all the hospitals, their director (head) was a project team member. In three out of four hospitals, managers of administrative units took part in task planning, while in over $2 / 3$ - heads of wards did. According to the respondents the following persons were accountable for planning: administrative staff - for half of the respondents, all hospital management - for nearly every fifth of them and non-managerial staff or technical staff - for one of respondents. An individual project team consisted of min. 1 person and max. 6 persons. The project team didn't participate in extra trainings/ courses on the planning of restructuring activities in the opinion of seven respondents from nine, who answered this question. According to the remaining, project team members underwent trainings on the commercialization of hospitals and operation of commercial companies.

No pre-implementation analysis (in order to specify needs) was not performed in their hospitals by opinion of three respondents. Only one person admitted that such a pre-implementation analysis was prepared jointly with the founding body, and two persons - with a consulting company. As for the remaining, this pre-implementation analysis was prepared with no consultation with the other party of the commercialisation process. In opinion of seven responders pre-analysis was conducted only by founding body (public entity), according to four person only by hospital.

Hospitals didn't organise any meetings for staff involved in such hospital operations in opinion of ten respondents. According to the remaining four persons meetings were organised in half of their units by the founding body or consulting company. At the same time every fourth hospital organised meetings with staff on its own.

As stated by eight of the respondents, action-plans were prepared only by founding body. According to four of them, it was only the hospital which was accountable for their preparation; as declared two persons - actionplans developed to implement transformation actions were defined jointly with the consulting company. The rest responders stated that a consulting company accounted for action-plans. Six responders believed that no one defined resources needed to accomplish set tasks. Out of the remaining $65 \%$, according to the majority of the respondents ( $81.8 \%$ - nine persons), their hospital accounted for resources needed to implement set tasks and two of the respondents declared that it was the founding body or consulting company.

In opinion of five respondents none of the entities (their hospital, founding body, consulting company or any other unit) didn't plan any budget for transformation. The remaining respondents $(71 \%)$ believed that the founding body was responsible for the budget (eight persons) while five of the respondents indicated it was their hospital itself. For one of the respondents, the budget was defined jointly with the establishing entity and according to two persons - by the hospital and a consulting company. Most of the respondents (twelve persons) admitted that no risk analysis was developed under planning transformation operations. Out of the remaining, it was the hospital which was responsible for such analysis (according to three persons) and in other cases it was the founding body.

None of the hospitals involved in the research studies developed any analysis on stakeholders as required for commercialisation. However, in the previous question on the identification of stakeholders, two of the respondents said that it was done. The respondents considered Health Department and Ownership Supervision Department at the Council Authorities to be the stakeholders. 
In case of all the respondents, planned actions get focused on the structure of debt where the primary task was to take over hospital debt by the establishing entity (by every responders). According to $94.1 \%$ of the respondents, planned actions also concerned the area of ownership (transformation). Operations in the structure of capital were planned by fourteen of the respondents, most often they (nine persons) pointed out to raising initial funds by their hospitals to appropriate levels. Changes in the field of services planned only five of respondents, most of which focused on expanding services which they provided and increasing their. In the field of ownership the key task was to acquire own assets by their hospitals (in the form of e.g. medical equipment or own buildings) - according to twelve respondents. In the area of work organisation, in which ten of the respondents planned activities, the most important issue was to reduce operating costs of their hospital (its divisions). In the area of staff changes were focused to adjust employment as required by their future company. Other areas such as sales, technical unit and management were marginal

In the course of the planning of restructuring operations, according to eight of the respondents there were problems with trade unions and in over $1 / 3$ cases - with the establishing entity. Nearly $1 / 4$ of the respondents declared that problems were due to unsatisfactory management of their hospitals, contracting issues and no financial resources to plan appropriate actions.

\section{Effectiveness of commercialisation and actions undertaken within it}

The effectiveness of commercialisation expressed in the form of the average degree of achievement of the primary target was calculated at a level of $82.4 \%$ for the first goal (reduction of debts), $55.8 \%$ for the second goal (reduction of liability for hospital funds incurred by the founding body) and $55 \%$ for the third goal (changes in work organisation, increase in economic and effective use of resources, adjustments in the quality of provided services to meet market requirements). The average success rate of planned actions in the area of debt structure was $100 \%$ - all the participating hospitals were converted into commercial companies. In the field of ownership the average success rate of implemented changes was assessed by the respondents at a level of $91.3 \%$. Failure to achieve $100 \%$ was due to non-recovery of hospital own property, acquisition of the majority stake by another entity than the establishing entity and no recapitalisation of newly established companies. In the structure of capital the average success rate was at $88.6 \%$ and came from insufficient initial capital held by companies. In the area of services, the average success rate was at $56.7 \%$, which was due to failure to expand services (add planned ones). In the area of property, the respondents rated it at $64.2 \%$, which was mainly due to failure to hold own property in spite of transformation operations. In the area of organisation and employment, the average success rate was $56 \%$ and $83.5 \%$, respectively. If it was possible to re-run restructuration of hospitals together with their commercialisation, the respondents would pay more attention to the following: needs analysis $(62.5 \%)$, setting of clear implementation targets (37\%), longer and more accurate preparation for changes (37.5\%) and improved communication between hospital staff and management as well as between their hospital management and establishing entities.

\section{Conclusions}

Commercialisation in itself is a formal change of ownership, therefore this is often just one element of broader restructuring efforts. Taking into consideration that restructuration run in hospitals stands for a series of actions aimed to reach a given goal, they are provisional in their nature, involve complex and coordinated tasks from various areas as well as need resources to be implemented, they can be said to be project-specific operations. It means that 
undertaken actions should be planned, implemented and evaluated on the basis of project management principles. When assessing actions undertaken by public hospitals in reference to project management, it should be stated that hospitals do not plan them on the grounds of the methodological guidelines of project management; some compliance of elements under restructuring plans with them is rather accidental than deliberate. It can be seen for example in: definition of goals which fails to use tools such as SMART, or failure to appoint a Steering Committee, faulty selection of project team members (e.g. heads of wards) and failure to conduct analyses on stakeholders and risks. A lack of standards in the field of planning and conducting restructuring operations in public entities leads to arbitrariness to manage such projects, and thus may increase risk due to failure to achieve their assumed level of effectiveness both at target and work-package levels.

The research studies and their results let to state that there are no top-down guidelines to plan the restructuring of public hospitals, so that each and every hospital approaches the process in a different manner. Nevertheless, it should be noted that the research studies were conducted in public hospitals located only in the Silesian Voivodeship, that successfully completed their commercialization process and operated now as commercial law companies. To be able to generalize conclusion and analyze exactly this phenomenon the research should be extended by a wider scope.

\section{References}

Brzozowska-Woś, M. (2013). Elektroniczne instrumenty komunikacji marketingowej w marketingu usług medycznych. Przedsiębiorczość i Zarządzanie, XIV (10).

Grupa Magellan (2014). Sytuacja finansowa szpitali w Polsce. Retrieved from: http://www.magellansa.pl/portals/1/files/raporty\%20 rynkowe/raport_sytuacja\%20finansowa\%20szpitali\%20w\%20polsce.pdf (14.07.2017).

Horosz, P., Grzesiak-Horosz, A., Skowron, K. (2012). Skomercjalizowane szpitale w obrocie gospodarczym. Warszawa: Wolters Kluwer Business.

Karkowski, T. (2014). Komercjalizacja i prywatyzacja szpitali w perspektywie dostarczania świadczeń zdrowotnych. Prace Naukowe Akademii im. J. Długosza w Częstochowie, Pragmata Tes Oikonomias, VIII.

Kocowski, T. (2012). Prywatyzacja zarządzania majątkiem publicznym, prywatyzacja majątkowa, prywatyzacja zadań publicznych i prywatyzacja wykonania zadań publicznych. In: J. Blicharz (ed.), Prawne aspekty prywatyzacji. Wrocław: ............wyd. ......??.

Marcinkowska, E. (2016). Sytuacja finansowa szpitali w kontekście procesu komercjalizacji. Prace Naukowe Uniwersytetu Ekonomicznego we Wrocławiu, 440.

NIK (2014). Działalność szpitali samorządowych przekształconych w spółki kapitałowe. Retrieved from: https://www.nik.gov.pl/plik/ id,8411,vp,10488.pdf (14.07. 2017).

Rabiega-Przyłęcka, A. (2013). Przekształcenia samodzielnych publicznych zakładów opieki zdrowotnej w spółki kapitałowe (w świetle przepisów ustawy o działalności leczniczej). Prace Naukowe Uniwersytetu Ekonomicznego we Wrocławiu, 319.

Stępniak-Kucharska, A. (2015). Przekształcenia własnościowe polskiej gospodarki w latach 1990-2012. Nierówności Społeczne a Wzrost Gospodarczy, 41 (1).

Ustawa z 16.06.2016 r. o zmianie ustawy o działalności leczniczej oraz niektórych innych ustaw, Dz.U. poz. 960.

Ustawa z 15.04.2011 r. o działalności leczniczej, Dz.U. nr 112, poz. 654.

Ustawa z 30.08.1991 r. o zakładach opieki zdrowotnej, Dz.U. nr 91, poz. 408.

Wiercińska, A. (2015). Wykorzystanie narzędzi zarządzania finansami na przykładzie szpitali województwa pomorskiego. Zeszyty Naukowe Uniwersytetu Szczecińskiego, 873. Finanse, Rynki Finansowe, Ubezpieczenia, 77.

Cite this article aS: Wielicka-Gańczarczyk, K. (2018). Commercialisation of public hospitals located in the Silesian Region - results of own research studies. European Journal of Service Management, 1 (25), 327-333. DOI: 10.18276/ejsm.2018.25-40. 